\title{
Implementation of Managerial Competence Headmaster in the New Era
}

\author{
Karinawati*, Diding Nurdin \\ Department of Educational Administration Program \\ Universitas Pendidikan Indonesia \\ Bandung, Indonesia \\ *karinawati280394@gmail.com
}

\begin{abstract}
The study aims to describe a picture of the implementation of managerial competence in a new normal era, using qualitative methods through interviews, documenting and analyzing qualitatively where the subject is headmaster and teacher. Studies have shown an image of the implementation of managerial competence of the headmaster in the new era, some of the factors affecting some; a) the headmaster has not yet had the appropriate competence standards; b) the headmaster's minimum experience; c) school tools and infrastructure were an adequate in the new normal era; d) at the time of the evaluation, the headmaster had not completed the optimal division of duties, authority and responsibility toward each area before carrying out the activity. The conclusion of the study is that at this new normal time there will be no need for everyone to worry particularly in improved education. All of this depends on how school directors identify problems and solve problems.
\end{abstract}

Keywords-implementation, headmaster managerial competence, new normal

\section{INTRODUCTION}

Competence is the authority and ability of a person to carry out a task or job in accordance with the position he has received [1]. Principals and teachers need to understand, have, and optimize the empowerment of these abilities in organizational behavior, especially in creating an active, creative, effective and enjoyable learning process [2]. One of them is the managerial ability of school principals in an effort to improve quality in schools / madrasahs. Management of successful madrasah principals when they understand the existence of madrasas as complex and unique organizations, and are able to carry out the role of the madrasah principal as someone who is given the responsibility to lead [3]. When viewed from the National Education System Law Number 20 of 2003, which states that education in madrasas is education equivalent to education in general, private MA (Madrasah Aliyah) education also has an equivalent position with Senior High School. and Vocational High School [4]. The head of madrasah as a manager needs to have managerial skills because it is very decisive in facilitating teaching and learning activities. The principal of madrasah is not only mastering management theories, more than that a madrasa principal must be able to implement his skills in real theory application [5] The principal / madrasah principal as a leader must be able to implement the managerial function in his management leadership because management activities always lead to the achievement of the expected organizational goals. Thus, management activities are always related to the functions of an organization which are often called managerial functions, which in general, educational management also has the same function, namely planning, organizing, directing and monitoring [6]. Managers (Principals of Schools / Madrasahs) in achieving organizational or institutional goals are required to have skills in order to carry out the necessary management functions. Another factor is optimizing community participation and control (supervision). Community participation in education is very strategic because it is the first and foremost environment for schools [7]. The implementation of the principal's managerial competence is very important in determining the success or failure of the school in carrying out the principal's duties to educate the nation's life and develop the whole human being. Good or bad a school is better determined by the professional ability of the principal as manager and the involvement of teachers in developing the school. As well as being a manager, the principal functions as a thinker and developer (brain power) whose main task is to think about the progress of the school [8]. Furthermore, argues that in order to show good performance, a principal must meet universal requirements including: a) basic skills or abilities, b) personal qualities, c) professional knowledge and d) professional skills. As a supervisor, coordinating the principal has a role to support, and guide the sustainable growth of teachers both individually and in groups, so that they are able to encourage and guide the sustainable growth of each student. As innovators, school principals provide opportunities for changes in school conditions both physically and psychologically [9].

One of the focuses of this study is the 16 dimensions of managerial competence which include; 1) preparing school / madrasah plans for various levels. 2) developing school / madrasah organizations according to needs 3) leading schools / madrasahs in order to make optimal use of school / madrasah resources, 4) managing changes and development of schools / madrasahs towards effective learning organizations 5) creating 
a school / madrasah culture and climate that is conducive and innovative for student learning 6) managing teachers and staff in order to optimize human resource utilization 7) managing school / madrasah facilities and infrastructure in order to optimize utilization 8) managing school / madrasah and community relationships in order to seek support, ideas, Learning Resources, and school financing 9) managing students in the context of admission of new students and placement and capacity building of students. 10) managing curriculum development and learning activities according to the direction and goals of national education 11) managing school / madrasah finances in accordance with the principles of accountable, transparent and efficient management 12) managing school / madrasah administration in supporting the achievement of school / madrasah goals 13) managing units special services for schools / madrasahs in supporting learning activities and student activities in schools / madrasahs 14) managing school / madrasah information systems in supporting programming and decision making 15) utilizing advances in information technology for improving learning and school / madrasah management 16) monitoring, evaluation [10]. To answer all these challenges, the principal of school / madrasah should be managed by referring to education management standards as regulated by Permendiknas No.19 of 2007. The direction of all of this is so that madrasah management can be carried out effectively and efficiently [11]

Consistent with this research, it has been extensively studied, but one that differentiates from another is the topic of the world-wide phenomenon covid-19. That Covid-19 directs global education to three fundamental changes, such as changing the pattern of children's education, new solutions for education that are able to give birth to new thoughts or innovations, the existence of a digital divide causing a shift in educational approaches and can widen this gap. if the government does not quickly respond and provide solutions to this condition [12]. The learning strategy refers to the new normal era guided by following health protocols and triggers teachers as part of human resources, most importantly in teaching and learning activities to have the right way to manage learning without face to face while not eliminating learning essence itself. To create innovation and improve the quality of schools at the time of the New Normal, schools should provide educational services with the alignment of new normal needs in order to create a match between schooling needs, in this case students, teachers, parents with current limited conditions (Covid-19) [13]. So that the attitudes and behavior of school personnel and students are reflective of the conditions of the Covid 19 pandemic towards achieving learning / school goals. The school principal certainly makes school strategies in implementing learning during the new normal, namely by continuing to carry out health protocols, and paying attention to the school environment in terms of the infrastructure needed during the Covid-19 pandemic.

Based on the explanation above, there are several previous studies that are in line with the title Implementation of Principal Managerial Competence, which include; The results of Saifullah's stated; The principal of Senior High School 2
Pulo Aceh has the capacity to guide students, is able to provide good teaching examples and is fully responsible for advancing the school, the principal can improve professionalism and is happy to receive suggestions and criticism from subordinates, and communicate policies and problems together, obstacles to the principal in carrying out managerial activities to improve the professionalism of teachers, it is not sufficient and the facilities and infrastructure for the smoothness of the educational process are still lacking [14]. The analysis and presentation carried out by Nur can be concluded that the quality of education and the quality of education in this new normal period can be realized if the leadership of the principal can be in the right role in order to be able to make himself the right and wise policy maker. Leaders must be able to identify and analyze each situation so that their responsibilities can be carried out properly. So that the principal in the Early Childhood Education institution is still able to maintain the quality and quality of education properly [15]. The statement above states that the research conducted by the principal plays an important role in activities to increase the productivity of teacher performance. Through their managerial abilities, the principal can understand what plans will be realized in carrying out activities in school institutions. The author feels that this study is different from other researchers because in the managerial competence of the principal, the researcher wants to see in depth the description of the implementation of the managerial competence of the headmaster in the new normal era.

Researchers feel that in new normal conditions, the principal should make careful planning and teamwork with teachers and staff at school. The principal managerial competence will always be determined by skills. According to Muraina, these skills are needed by school principals in order to improve school effectiveness, namely communication skills, decision-making skills, disciplinary skills, and organizational skills. According to him, in the framework of systems thinking, this skill is considered an input system and has implications for the effectiveness of the principal's administration to improve school performance [16].

\section{LITERATURE REVIEW}

\section{A. Corona Virus Diseases}

Coronavirus is one of the major pathogens that primarily targets the human respiratory system. Previous outbreaks of coronaviruses (CoVs) include the severe acute respiratory syndrome (SARS)-CoV and the Middle East respiratory syndrome (MERS)-CoV which have been previously characterized as agents that are a great public health threat. In late December 2019, a cluster of patients was admitted to hospitals with an initial diagnosis of pneumonia of an unknown etiology. These patients were epidemiologically linked to a seafood and wet animal wholesale market in Wuhan, Hubei Province, China [1,2]. Early reports predicted the onset of a potential Coronavirus outbreak given the estimate of a reproduction number for the 2019 Novel (New) Coronavirus 
(COVID-19, named by WHO which was deemed to be significantly larger than 1 (ranges from 2.24 to 3.58 ) [17]. Covid-19 has become something terrible since the start of 2020. The spread of the virus so fast and massive make many countries in this world overwhelmed to face this global pandemic. Apart from the fatal human casualties and the disruption of millions of human lives, education problems occur significantly. In the face of particular challenges and an uncertain set of risks, education leaders and stakeholders are concerned about how their education will be affected and what they should do next. The Covid-19 pandemic will likely accelerate the inevitable fundamental and structural changes in any case. Everything happened much faster than it should have. Consider that the "virtualization" of work is done from home or elsewhere, with collaboration and distance learning policies and travel reduction for physical encounters having been steadily developing. Today, all over the world, businesses are learning to communicate, collaborate, and coordinate on virtual platforms, and understand the increased efficacy and efficiency that these work modalities can provide. Virtual work and collaboration tools are likely to create new, booming market spaces [18].

\section{B. Managerial Abilities of School Principals During Covid- 19}

Efforts to improve the quality of education in schools need to be supported by abilities Managerial Principal. The principal should strive to utilize both personal and material resources effectively and efficiently in order to support the achievement of educational goals in schools optimally [19]. In a way that has been done by the education and culture government in discussing the ability of school principals during the Covid-19 pandemic, the managerial principals should develop with opportunities to provide excellent service that is innovative, motivating, and has a selling value for students. This has been done together with the teachers. and other education personnel in schools. One of them is through online lesson study videos that have been uploaded to the YouTube video sharing site. as well as for students to implement character education that is instilled starting from home and habituation in this new normal period [20].

\section{RESEARCH AND METHODS}

This research uses qualitative research with a content analysis descriptive design, which puts forward data research or the reality of the problem based on expressions by respondents and data collected in the form of interviews, plus some other documentations. The object of this research is the head of the Madrasah and some of the teaching staff of Riyadhul Huda Nagreg and the factors that become obstacles in implementing managerial competence in the middle of the new normal by understanding and interpreting the views and events of respondents in order to analyze the competence of a leader and the role of the principal.

\section{RESULTS AND DISCUSSION}

Implementation of Headmaster Managerial Competence at Islamic Junior High School Riyadhul Huda Nagreg Kab. Bandung

\section{A. School Planning}

Planning is carried out at Islamic Junior High School Riyadhul Huda Nagreg, carried out through the preparation of an early-year planning program and submitting each program item to be implemented to all teachers, staff and employees who are partners or colleagues at the school. However, in the implementation in this new normal era, the principal did not involve the teachers, staff and employees in making planning programs. So that it makes some teachers less interact with the principal, and also with this new normal, the role of the principal in planning school programs is needed.

\section{B. School Organization}

In order to develop schools in accordance with the needs carried out by Islamic Junior High School Riyadhul Huda Nagreg, namely completing all the needs needed by teachers in the teaching and learning process in schools so that you are interested in the learning process provided by teachers in the groups. However, the reality in the field has not yet been developed by the principal in order to develop schools according to the needs of schools in the new normal era. So what happens is the response from the teacher to teaching students is less and the obstacles faced by the teacher to develop according to the teacher's narrative there are more students who do not focus on learning.

\section{Empowerment of School Resources and Human Resources}

Maintain and care for all assets in the school and send teachers for training, both through the Teacher wok group and the training that is carried out by the local government, attended the Webinar. Islamic Junior High School Ryadhul Huda has not been able to empower and improve school resources and human resources in the environment because the results of documentary observations in the field show that there are no documents on the list of teacher training programs, in fact, in this condition, there are a lot of training carried out by the Ministry of Education and Culture through webinars and free training through online to hone the ability of teachers to be more literate about information and technology.

\section{School Management}

In order to manage change and development of Islamic Junior High School Riyadhul Huda school towards effective learning, namely involving teachers in implementing a student center so that students are more active in learning and each student is able to express his opinion. In its implementation, according to the words of one of the 7 th grade teachers, "students are still less active even though the teachers try not to feed the students and also moreover there are students who are clueless about gadgets which at least hamper the teaching 
process" he said. This is because the school is still not facilitating the needs of students and involving teachers in demonstrating effective learning programs and with the existence of Covid-19 students are starting to train and get used to playing devices for independent learning.

\section{E. School Culture and Climate}

Creating a culture and climate that is conducive and innovative for student learning at Islamic Junior High School Ryadhul Huda Nagreg, namely teachers and students are required to be present 15 minutes before the bell rings, students are required to wear uniforms that have been determined by the school and how teachers can manage classrooms properly and create media in the learning process so that students are more interested and can understand every lesson delivered by the teacher and especially with the covid-19 culture of wearing masks and washing hands must be applied when studying. Whereas in its implementation, no effort has been made considering Islamic Junior High School Ryadhul Huda is in the same scope as the Islamic Boarding School, which automatically students do not discipline themselves to follow the existing rules. The culture of wearing sandals and sarongs has become a tradition of Islamic boarding school children even when students practice such culture or habits, and for students, in fact, many still ignore health protocols on the grounds that students never leave the Islamic boarding school so that students in the school environment are considered safe. And for teachers, after being seen, they have not made new innovations in school progress because of the limitations of their own schools.

\section{F. Empowerment of Teachers and Staff}

Managing teachers and staff in the context of utilizing human resources at Islamic Junior High School Ryadhul Huda by holding school meetings, discussing deficiencies in the school environment and directing teachers in the implementation of making learning tools such as syllabus and lesson plans at home so that they are more focused in providing material to students at school. In managing staff, schools provide advice and direction in making school documents and data so that school needs are fulfilled. Whereas in reality, especially with this new normal condition, the teacher to make the learning exercise plan implementation of learning experienced obstacles, one of which was the problem of internet connection and the unclear emergency curriculum that was launched by the government.

\section{G. School Facilities and Infrastructure}

Manage facilities and infrastructure Islamic Junior High School Riyadhul Huda Nagreg by maintaining the existing facilities and infrastructure so that they can be used properly and the school designating the facilities and infrastructure to make complete data available at the school. Meanwhile, in its implementation, the principal assigns the task of the head of the facilities and infrastructure sector to list the facilities and infrastructure in the school, for example making a recap of the number of benches, chairs, books and moreover, he is obliged to make a sink for washing hands and even soap due to this condition in schools., as well as schools trying to submit proposals to the Education Office in order to add facilities and infrastructure needed at schools.

\section{H. School Cooperation Relationship with the Community}

Managing school and community relationships in order to find support, ideas, learning resources and funding at Islamic Junior High School Ryadhul Huda, namely always holding meetings with committees, parents, guardians of students and community leaders to find the best solution in providing ideas for schools, especially in learning resources that have not been fulfilled by the school see the place close to the boarding school and also with the implementation of this new normal, learning resources in the form of a strong internet network are needed for the sustainability of students. Meanwhile, in the context of seeking school funding, the school never asks the parents of the guardians of students and the community because the environment that is integrated with the Islamic boarding school is always a donation for the school even though it does not force the student's family.

\section{Student}

Managing students in the context of admitting new students, placing and developing the capacity of students at Islamic Junior High School Ryadhul Huda, namely forming a committee for new student admissions, looking for or visiting each elementary school to get students who are interested in entering the school, carrying out a school orientation period at home using video media by using the creativity of students. The school principal's plan for this has been implemented well, and for students who are accepted, the committee is only given directions in the form of things to prepare to start school by observing health protocols.

\section{J. Curriculum}

Manage curriculum development and learning activities in accordance with the direction and goals of the school at Islamic Junior High School Ryadhul Huda by conducting deliberations to reach a solution to every problem in the student learning process, because with the current situation schools and teachers are required to make an emergency curriculum that makes it easier for teachers and students in the process. learning. With the ease of the blanded learning system, teachers and students do not meet face to face every day but school policies provide a time difference for each generation.

\section{K. School Finances}

Managing school finances in accordance with the principles of accountable, transparent, efficient management at Islamic Junior High School Riyadhul Huda Nagreg, namely management of funds which is carried out transparently and any funds received from the government such as BOS funds and routine funds are directly managed by the treasurer and administrative staff. Due to this new normal condition for the 
management of BOS funds, schools made an initiative to deduct student tuition fees from the BOS funds, the remaining funds were given to parents to buy electronic money or online needs. Furthermore, the treasurer submits SPJ for each fund that is managed both in the form of income and expenditure.

\section{School Administration}

Managing school administration supports the achievement of goals at Islamic Junior High School Ryadhul Huda, which is to provide technical guidance, functions and school administrative duties. The reality in the field is that administration has been able to properly manage school administration even though it still has to study and attend training. For now, the new normal administration is overwhelmed in serving the parents by completing several files that must be collected online.

\section{Special Service Unit}

Manage Special school service units in supporting learning activities and student activities still have shortcomings such as long counseling guidance before Covid-19 there was counseling there was still no special teacher but was still handled directly by school leaders. Seeing the current condition that counseling is needed because it monitors children for progress in learning through this blanded learning.

\section{N. Management of School Information Systems}

Managing school information systems in support of programming and decision making at Islamic Junior High School Ryadhul Huda Nagreg yaitu by looking for information carefully, information from outside the school to compile school programs and revise those that are not yet on target. Meanwhile, in decision making, meetings are held with representatives of school principals or each school cluster to seek information or policies that will be taken in determining joint decisions.

\section{O. Information and Communication Technology}

The use of information technology to improve learning and the school management system at Islamic Junior High School Riyadhul Huda Nagreg has not yet been implemented considering the new normal condition is still limited to space. Facilities and infrastructure as well as local conditions that are not yet supportive to support the learning process, so that information technology is still partially or in turn to be used in the teaching and learning process in schools.

\section{P. Monitoring, Evaluation and Reporting}

To do monitoring, evaluating and reporting the implementation of school activity programs with proper procedures and planning follow-up actions at Islamic Junior High School Ryadhul Huda Nagreg, which is monitoring or supervising teachers in the classroom, observing the plans that have been carried out by the teacher during the learning process and providing input to the teacher supervised. The next step is to evaluate program activities in schools such as teacher supervision and evaluation of teacher activity processes. However, at the time of implementation in the field in new normal conditions like this, the principal had difficulties because the policy for active schooling was still changing. So the steps taken by the principal are monitoring teacher teaching activities online.

\section{CONCLUSION}

Based on the results of the research on the implementation of the principal managerial competence of Islamic Junior High School Ryadhul Huda in the new normal period, this has not been carried out properly. This means that during this new normal period there is no need for all parties to worry, especially in improving the quality of education. All of this depends on how the school leader or principal identifies problems and determines the appropriate leadership style for solving problems that must be resolved in every form of situation and condition. Be it during this new normal, pandemic or other times.

\section{REFERENCES}

[1] M. Rohimat, "Implementasi Kompetensi Manajerial Kepala Sekolah dalam Mewujudkan Prestasi Sekolah Pada SMA Negeri," Indones. J. Educ. Manag. Adm. Rev., vol. 3, no. 1, pp. 62-70, 2019.

[2] A. Kurniawan, "Kemampuan Manajerial Kepala Sekolah Dalam Meningkatkan Kinerja Guru Untuk Menciptakan Sekolah Yang Bermutu Penelitian di SDIT Sabilul Huda dan SDIT Sains al-Farabi," J. Holostik Islam. Soc. Sicences, vol. 12, no. 5, pp. 25-51, 2011.

[3] Baryanto, "Manajemen Kepala Madrasah Dalam Meningkatkan Kualitas Pendidikan Di MTS Nurul Kamal Kabupaten Rejang Lebong Baryanto Sekolah Tinggi Agama Islam Negeri ( STAIN ) Curup Pendahuluan Manajemen Kepemimpinan sebagai salah satu fungsi manajemen merupakan hal yan," TADBIR J. Stud. Manaj. Pendidik. vol. 1, no 02, 2017 Sekol. Tinggi Agama Islam Negeri Curup, vol. 1, no. 02, pp. 242272, 2017.

[4] H. Sodiqin and D. Nurdin, "Kontribusi Kemampuan Manajerial Kepala Madrasah dan Kinerja Mengajar Guru terhadap Mutu Madrasah Aliyah Swasta," vol. 10, no. November, pp. 165-178, 2017.

[5] M. Akli, "Keterampilan Manajerial Kepala Madrasah dalam Mempertahankan Eksistensi Mafrasah Tsanawiyah Nahdhatul Ulama Haruyan Kabupaten Hulu Sungai Tengah,” Institut Agama Islam Negeri Antasari, 2014.

[6] N. Hasanah, "Kepemimpinan Kepala Sekolah Dalam Pengembangan Lembaga Pendidikan," al-Iltizam J. Pendidik. Agama Islam, vol. 2, no. 1, pp. 1-14, 2017, doi: 10.33477/alt.v2i1.323.

[7] M. Walid, "Keterampilan Manajerial Kepala Madrasah/Sekolah Dalam Meningkatkan Mutu Lulusan Muhammad Walid Dosen pada program studi PGMI dan PAI UIN Malang," vol. 1, no. 1, 2008

[8] A. P. Kurniawati, "Implementasi Kompetensi Manajerial Kepala Sekolah dalam penyususnan Rencana Pengembangan Sekolah Menuju sekolah Program Khusus di MI muhammadiyah Bolon,” 2018.

[9] A. Mashar, "Hubungan sifat-sifat Kepemimpinan dan Pengetahuan Komunikasi dengan Kinerja Kepala SD di Bandar Lampung,” Ahsanta J. Pendidik., vol. 5, no. 2, pp. 30-39, 2019

[10] "Peraturan Menteri Pendidikan Nasional Republik Indonesia Nomor 13 Tahun 2007," 2007.

[11] A. Al-Falah, S. Supiah, and S. S. Posangi, "Pengelolaan Madrasah dalam Meningkatkan Mutu Pendidikan di Madrasah Aliyah 
Muhammadiyah Kota Gorontalo,” Tadbir J. Manaj. Pendidik. Islam, vol. 7, no. 1, pp. 37-44, 2019, doi: 10.30603/tjmpi.v7i1.1055.

[12] N. Kaseje, "The World Economic Forum COVID Action Platform," Why Sub-Saharan Africa needs a unique response to COVID-19, 2020.

[13] J. M. Bisnis, "Peningkatan Human Capital Dalam di Era New Normal," vol. 17, no. 3, pp. 425-444, 2020.

[14] Syiah and K. Jafar, Zulkarnaen, "Kompetensi Manajerial Kepala Sekolah Dalam Meningkatkan Kinerja Guru Pada Smp Islam Terpadu Al-Fityan Kabupaten Aceh Besar," J. Adm. Pendidik. Progr. Pascasarj. Unsyiah, vol. 6, no. 1, pp. 36-44, 2018.

[15] Nur Hazizah, "Leadership Headmaster in Improving the," SPEKTRUM J. Pendidik. Luar Sekol., vol. 8, no. 2, pp. 142-146, 2020, doi: 10.24036/spektrumpls.v8i2.109155.
[16] M. Babatunde, "Principals' Managerial Skills and Administrative Effectiveness in Secondary Schools in Oyo State, Nigeria," vol. 14, no. 3, 2014.

[17] WHO, "Naming the coronavirus disease (COVID-19) and the virus that causes it," World Health Organization.

[18] K. D. Nguyen et al., "Opportunities for education during the COVID-19 pandemic," JAAD Int., vol. 1, no. 1, pp. 21-22, 2020, doi: 10.1016/j.jdin.2020.04.003.

[19] D. I. K. Subang and O. E. Karweti, "Pengaruh kemampuan manajeria kepala sekolah dan faktor yang mempengaruhi motivasi kerja terhadap kinerja guru slb di kabupaten subang," 2010. .

[20] "Mengembangkan Kompetensi Kepala Sekolah di Masa Pandemi," 2020 